Article type: paper

Date text revised 26-12-2014

The main text contains: 4306 words (without References), 6 tables and 4 figures.

\title{
Evaluation of short- and long-term properties of heat cured alkali-activated fly ash concrete
}

Author 1

- Julia Shekhovtsova

- $\quad$ PhD student, Department of Civil Engineering, University of Pretoria, Pretoria, South Africa

- $\quad$ j.shekhovtsova@gmail.com

Author 2

- $\quad$ Maxim Kovtun, $\mathrm{PhD}$

- $\quad$ Researcher, Department of Civil Engineering, University of Pretoria, Pretoria, South Africa

- $\quad$ max.kovtun@up.ac.za

Author 3

- $\quad$ Elsabe P. Kearsley, PrEng, MEng, PhD, FSAICE, FSAAE

- $\quad$ Professor, Head of Department of Civil Engineering, University of Pretoria, Pretoria, South Africa

- $\quad$ elsabe.kearsley@up.ac.za

Contact details of corresponding author:

Julia Shekhovtsova

Tel.: +27 124204179

Fax: +27 123625218

Email: j.shekhovtsova@gmail.com

Department of Civil Engineering, University of Pretoria, Pretoria, 0002, South Africa 


\begin{abstract}
Short and long-term properties of alkali-activated fly ash concrete namely compressive, flexural and splitting tensile strengths, modulus of elasticity, Poisson's ratio, early age and drying shrinkage, creep, and durability performance have been investigated in this paper. Blended ordinary Portland cement-fly ash concrete was used as a reference. The average compressive and flexural strength of alkali-activated fly ash concrete at 28 days was $45 \mathrm{MPa}$ and 5.8 MPa respectively; drying shrinkage and creep values were about 360 and 200 microstrain respectively at one year. The total early age shrinkage during the first 24 hours of curing was lower for alkali-activated fly ash concrete of 1460 microstrain compared to 2800 microstrain for blended cement concrete. The using of this nonPortland cement containing material for producing precast concrete units can utilize high volumes of fly ash and potentially reduce the carbon footprint of the final product.
\end{abstract}

\title{
Keywords
}

Concrete technology \& manufacture; Materials technology; Strength and testing of materials 


\section{Introduction}

During the last decade interest in alkali-activated binders and geopolymers increased significantly, suggesting that these binders have a big potential as an alternative binder to ordinary Portland cement (OPC). Geopolymers are formed by activation of aluminosilicates with alkaline solution (Heath et al., 2014). The carbon footprint of geopolymer concretes can be less than that of OPC concretes (McLellan et al., 2011; Turner and Collins, 2013). Moreover, using high volumes of industrial byproducts, such as fly ashes, slags, rice husk ash, etc. as a source of aluminosilicates, will expand the raw-material base of the building industry, preserving natural resources and reducing waste to landfill. Good mechanical and durability performance could be another benefit of geopolymer production.

Ultra-high performance geopolymer concrete with compressive strength over $120 \mathrm{MPa}$ was developed using granulated blast furnace slag and silica fume (Ambily et al., 2014). Ferreira et al. (2014) reported possible using of alkali-activated concrete for producing precast façade panels. From previous studies (Bakharev, 2005; Kovalchuk et al., 2007; Criado et al., 2010) it was found that fly ash based alkali-activated materials/geopolymers require heat curing conditions to get good mechanical strength. Rangan (2009) reported 7-days compressive strength of heat cured low-calcium fly ash-based geopolymer concrete of more than $50 \mathrm{MPa}$.

In previous works some properties of heat cured geopolymer concrete were investigated (Hardjito and Rangan, 2005; Fernandez-Jimenez et al., 2006; Sofi et al., 2007; Rangan, 2009; Reddy et al., 2013). It was shown that heat-cured geopolymer concrete possess good compressive strength, low drying shrinkage and creep, and good resistance to sulphate, acid and chloride attack. Few studies have been performed to investigate the shrinkage behaviour of geopolymer concretes (Sagoe-Crentsil et al., 2013; Fernandez-Jimenez et al., 2006; Hardjito and Rangan, 2005). Research highlight drying shrinkage of concrete, while the early age shrinkage was not considered. Lee (2007) studied early age shrinkage of ambient cured high-calcium fly ash inorganic polymer during the first 24 hours. The results shown that inorganic polymer can have high early age shrinkage potential and a high rate of 
shrinkage. Shrinkage of alkali-activated fly ash concretes during heat curing was not investigated previously; although initial shrinkage that occurs during heat curing can significantly contribute to the total shrinkage and be a reason for early-age cracking of concrete. Thus, in-situ evaluation of shrinkage of $\mathrm{NaOH}$-activated fly ash concrete during heat curing is reported in this paper in addition to short- and long-term engineering properties. Evaluation of properties such as compressive, splitting tensile and flexural strength, modulus of elasticity and Poisson's ratio, drying shrinkage, creep and durability performance is essential before alkali-activated concrete can be used as structural material.

\section{Experimental work}

\subsection{Materials}

Classified low calcium fly ash from Lethabo power station with more than $80 \%$ particles with particle size smaller than $45 \mu \mathrm{m}$ was used in alkali-activated fly ash concrete (denoted as GP) as well as for partial replacement of OPC CEM I 52.5N (PPC Pty Ltd, South Africa) in blended cement concrete (denoted as OPC-FA). The chemical composition of the fly ash and OPC is shown in Table 1. OPC-FA concrete was produced not for direct comparison of mechanical strength with GP but rather as an indicator of other properties (durability, creep and shrinkage). Sodium hydroxide flakes ( $98.5 \%$ purity) obtained from Protea Chemicals, were dissolved in distilled water in order to obtain an activating solution. The activator solutions were prepared and cooled down to room temperature before mixing. The $\mathrm{Na}_{2} \mathrm{O}$ content in the mixture has been calculated as percentage of fly ash mass. Dolomite sand with a fineness modulus of 3.86 and $9 \%$ passing the $75 \mu \mathrm{m}$ sieve was used to produce alkali-activated fly ash concrete. Crushed dolomite stone $(9.5 \mathrm{~mm})$ was used as the coarse aggregate for the concretes.

\subsection{Specimen preparation and curing}

Table 2 provides mix proportions for the concretes. Both GP and OPC-FA concretes were designed to contain the same amount of binder, $500 \mathrm{~kg}$ per cubic meter. Water to cement ratio of OPC-FA was chosen so its consistency was similar to GP. The fine to coarse aggregate percentage ratio was kept constant at 35:65 for both GP and OPC-FA concretes. 
All GP samples were cured at $60{ }^{\circ} \mathrm{C}$ in a dry oven for 24 hours. Then some samples were kept in a room with constant conditions $\left(25^{\circ} \mathrm{C}\right.$ temperature and $55 \%$ of relative humidity) and other samples were kept in water until testing. A third group of GP samples was cured in room with constant conditions but 24 hours before testing were placed into water. Different post-curing conditions of GP concrete were chosen to see their effect on compressive strength and other properties. OPC-FA concrete samples were cured in a fog room for the first 24 hours and then samples were kept in water until testing.

\subsection{Testing}

\subsubsection{Strength}

The compressive strength test was conducted on $100 \mathrm{~mm}$ cubes at a rate of $0.25 \mathrm{MPa} / \mathrm{s}$. Three cubes were tested in compression at $1,7,28,91,182$ and 364 days.

Beam samples with dimensions of $100 \times 100 \times 500 \mathrm{~mm}$ were subject of four-point bending to determinate the modulus of rupture. For splitting tensile strength, concrete cylinders with diameter of $150 \mathrm{~mm}$ and height of $300 \mathrm{~mm}$ were cast and subjected to compressive forces, at a rate of $0.03 \mathrm{MPa} / \mathrm{s}$, applied along two diametrically opposed lines. The tests were conducted at 28 days.

\subsubsection{Deformations and volume change}

Concrete cylinders $150 \times 300 \mathrm{~mm}$ were used for measuring E-value and Poisson's ratio, at 28 days.

The Schleibinger shrinkage cone method (Eppers and Müller, 2010) was adopted for measuring insitu volume changes of unsealed GP concrete during heat curing at $60^{\circ} \mathrm{C}$. Shrinkage of OPC-FA normal cured concrete during the first 24 hours was recorded as well. As blended cement concrete was cured in a high humidity room (about $99 \%$ relative humidity) shrinkage of OPC-FA can be considered as autogenous, while the volume changes of GP concrete during heat curing could be caused by thermal expansion, drying shrinkage and chemical shrinkage which cannot be separated. 
Drying shrinkage measurements for both GP and OPC-FA concretes were conducted on $100 \times 100 \times 300 \mathrm{~mm}$ beams. The drying shrinkage measurements of GP started right after heat curing $\left(60{ }^{\circ} \mathrm{C}\right.$ for 24 hours) and cooling of samples. OPC-FA samples were cured in water bath for 6 days and the first reading measurement was taken on the $7^{\text {th }}$ day. During the test, samples of both concretes were stored in a room with constant temperature and relative humidity $\left(25^{\circ} \mathrm{C}\right.$ and $55 \%$ respectively).

Creep behaviour of GP concrete and OPC-FA blended cement concrete was studied on $150 \times 300 \mathrm{~mm}$ cylinders. Creep test of the first set of GP samples commenced immediately after heat curing under sustained stress of $40 \%$ of the compressive strength on this day. The second set of GP samples after heat curing was placed in a room with constant temperature and humidity $\left(25{ }^{\circ} \mathrm{C}\right.$ and $\left.55 \%\right)$. After 28 days samples were placed under sustained stress of $40 \%$ of the 28 -days compressive strength. OPCFA samples were cured in water and placed under sustained stress on the $28^{\text {th }}$ day of curing. Creep was calculated in microstrain.

\subsubsection{Durability}

To evaluate the durability of the concretes, techniques, known in South Africa as durability indexes, were applied to both concretes (Alexander et al., 1999). Cores with diameter of $68 \mathrm{~mm}$ were cut from $150 \times 150 \mathrm{~mm}$ concrete cubes and then sliced into $30 \mathrm{~mm}$ thick discs for determination of chloride conductivity, oxygen permeability, water sorptivity and porosity of concretes.

Samples for oxygen permeability testing were placed into a permeability test chamber and oxygen under pressure $(100 \pm 5 \mathrm{kPa})$ was allowed to flow though the permeability cell. Pressure readings were automatically taken until the pressure dropped to $50 \pm 2.5 \mathrm{kPa}$, or for $6 \mathrm{~h} \pm 15 \mathrm{~min}$, whichever comes first. The coefficient of permeability is determined according to Equation 1.

$k=\frac{\omega V g d z}{R A \theta}$ 
1.

Where, $k$ is the coefficient of permeability of the test sample $(\mathrm{m} / \mathrm{s}), \omega$ is the molecular mass of oxygen $(0.032 \mathrm{~kg} / \mathrm{mol}), \mathrm{V}$ is the volume of oxygen under pressure in the permeameter $\left(\mathrm{m}^{3}\right), \mathrm{g}$ is the acceleration due to gravity $\left(\mathrm{m} / \mathrm{s}^{2}\right), \mathrm{R}$ is the universal gas constant $(8.313 \mathrm{~N} \cdot \mathrm{m} / \mathrm{K} \cdot \mathrm{mol})$, A is the crosssectional area of the sample $\left(\mathrm{m}^{2}\right), d$ is the sample thickness $(\mathrm{m}), \theta$ is absolute temperature $(\mathrm{K}), z$ is the slope of the line produced when the natural log of the ratio of initial pressure to pressure at any time is plotted against time (Equation 2).

$$
z=\frac{\sum\left[\ln \left(\frac{P_{0}}{P_{t}}\right)\right]^{2}}{\sum\left[\ln \left(\frac{P_{0}}{P_{t}}\right) t\right]}
$$

2.

Where $P_{0}$ is the initial pressure at the start of the test, and $P_{t}$ are the subsequent readings in pressure at times $t$, measured from the time of reading of initial pressure $t_{0}$.

The 'permeability index' is calculated as a negative log of the average of the coefficients of permeability of the four samples (Equation 3).

$O P I=-\log _{10}\left[1 / 4\left(k_{1}+k_{2}+k_{3}+k_{4}\right)\right]$

3.

Water sorptivity testing consists of measuring the mass of water absorbed with time from the bottom of a concrete sample, of which the sides have been sealed. The sorptivity was determined from the slope of the straight line produced when the mass of absorbed water is plotted against the square root of time, multiplied by the sample thickness, and divided by the difference between the vacuum saturated mass of sample and its dry mass. The test result was calculated as the mean of four determinations. 
Chloride conductivity testing consists of measuring the electrical current passed through $30 \mathrm{~mm}$ thick slices of $68 \mathrm{~mm}$ diameter core. The specimens were saturated with $5 \mathrm{M} \mathrm{NaCl}$ solution before the test. A potential of $10 \mathrm{~V}$ was applied across the ends of the specimen, which was immersed in a sodium chloride solution. The conductivity was determined from the specimen dimension and the specimen electrical resistance $(($ thickness/area $) \times($ current/potential difference $)$. Test results were calculated as the mean of four determinations.

The porosity (n) of each specimen was determined using Equation 4.

$n=\frac{M_{s v}-M_{s 0}}{A d \rho_{w}} \times 100$

4.

Where, $M_{s v}$ is the vacuum saturated mass of the specimen, $\mathrm{g} ; M_{s 0}$ is the mass of the specimen at time $\mathrm{t}_{0}, \mathrm{~g}$; A is the cross-sectional area of the specimen, $\mathrm{mm}^{2} ; d$ is the average specimen thickness, $\mathrm{mm} ; \rho_{w}$ is the density of water, $10^{-3} \mathrm{~g} / \mathrm{mm}^{3}$.

\section{Results and discussion}

\subsection{Strength}

The unit-weight of the GP concrete after heat curing was $2395 \mathrm{~kg} / \mathrm{m}^{3}$, which is similar to $2438 \mathrm{~kg} / \mathrm{m}^{3}$ of OPC-FA concrete. The compressive strength development of concretes is shown in Figure 1.

The compressive strength of GP concrete samples after 24 hours of heat curing was $32.5 \mathrm{MPa}$. Temperature increase results in intensive polymerization reaction and gain of compressive strength (Palomo et al., 1999). However, strength development does not stop with discontinuation of heat curing and strength is continuously gained until 91 days and reaches 57.0 MPa, suggesting that the transformation process of main reaction products is still going. No significant strength gain was 
observed after 91 days with the compressive strength of GP concrete after one year being 59.4 MPa. Thus more than $50 \%$ of final concrete strength was reached during heat curing.

The compressive strength of GP samples submerged in water for 24 hours before testing was only 5 to $10 \%$ lower than that cured in dry conditions at different ages, showing that the GP concrete has good water resistance. The 28-days strength of GP cured in dry conditions was $45.5 \mathrm{MPa}$, while for samples cured in water it was $44.8 \mathrm{MPa}$. It seems that curing in dry condition is preferable for alkali-activation and, as a result, for compressive strength of GP concrete. This becomes more prominent with age with the 91-days compressive strength of GP samples cured in dry conditions and water reaching 57.0 MPa and 48.4 MPa respectively. Strength development of GP concrete is slower in water, as by the end of a year samples cured in dry condition gain up to $80 \%$ on the initial compressive strength, while samples cured in water gain only $45 \%$ on the initial compressive strength. According to these results subsequent curing (storage) of heat cured alkali-activated fly ash concrete by immersing in water, which is usually employed for OPC concrete, is not recommended.

Usually concrete is not expected to resist direct tension; however, the values of tensile strength of concretes give an idea of the load at which concretes may crack, as cracking is a form of tension failure. Table 3 presents the results of modulus of rupture and split cylinder strength of GP and OPCFA concretes at 28 days.

GP concretes showed split cylinder strength in the same range than that of OPC-FA concrete despite the great difference in the 28-days compressive strengths. Water curing and soaking of GP concrete have a negative influence on the tensile strength, which correlates with compressive strength results.

The tensile strength of concrete is usually ignored in the design of concrete structures; however the design of concrete roads and pavements is based on flexural strength of concrete. According to the Portland Cement Association, as cited in Addis (1994), flexural strength may be taken as it shown in Equation 5. 
$f_{f}=K f_{c}^{1 / 2}$,

5.

Where, $f_{f}$ is the flexural strength, MPa; $f_{c}$ is the cube compressive strength, MPa and $K$ has a value of 0.68 .

The Joint CEB-FIB Committee, as cited in Addis (1994), used the following relationship between compressive and tensile strength (Equation 6).

$f_{t}=0.24 f_{c}^{2 / 3}$,

6.

Where $f_{t}$ is the split cylinder strength and $f_{c}$ is the cube strength, MPa.

Table 3 shows the results of calculated values of tensile strength. The results show that the measured flexural and split tensile strength of GP concretes is higher than the predicted though calculations values. Similar trends were observed by Rangan (2009).

\subsection{Deformation and volume change}

In Table 4 the static of modulus of elasticity and Poisson's ratio of concretes at 28 days are shown.

The E-value of GP concrete is insignificantly greater for samples cured in dry condition, which correlates with the compressive strength at the same age. The values of elastic modulus of GP are significantly lower compare to OPC-FA. However, the comparison of these two values is unfair due to the different concrete grades to which GP and OPC-FA can be assigned. In general the elastic modulus of GP concrete is lower than that of OPC concretes of similar grade with the same type of 
aggregate. Alexander (1994) reported static elastic modulus of $37 \mathrm{GPa}$ for $30 \mathrm{MPa}$ OPC concrete and $44 \mathrm{GPa}$ for $40 \mathrm{MPa}$ concrete at 28 days. Lower elastic modulus for GP concrete can be caused, for example, by the weaker transition zone between aggregate and paste for GP concretes due to higher porosity or elastic properties of aluminosilicate gel (main product of fly-ash alkali-activation).

Alexander and Davis (1992) suggested the relationship between compressive strength and modulus of elasticity of concrete made with South African aggregates, shown in Equation 7.

$E=K_{0}^{\prime}+\alpha f_{c u}$

7.

Where $E$ is the static modulus of elasticity at 28 days, $\mathrm{GPa} ; f_{c u}$ - characteristic cube strength, MPa,; $K_{0}^{\prime}$ - a constant related to the stiffness of the aggregate, $\mathrm{GPa} ; \alpha$ - a strength factor, also related to the aggregate characteristics, GPa/MPa.

If we assume that, the characteristic strength of GP is $30 \mathrm{MPa}$. The values for $K_{0}^{\prime}$ and $\alpha$ for dolomite aggregate can be taken as 24 and 0.45 respectively (Alexander and Davis, 1992). The calculated elastic modulus of GP at 28 days is $37.5 \mathrm{GPa}$. It can be seen (Table 4) that the measured E-values are about $20 \%$ lower than the calculated E-value. If the same degree of quality control will be assumed for OPC-FA concrete as for GP, the characteristic strength of OPC-FA concrete at 28 days will be 45 MPa. In this case the calculated elastic modulus will be $44.2 \mathrm{GPa}$ which is very close to the measured value shown in Table 4. The nature and elastic properties of GP binder differ from that of OPC binder resulting in a substantial difference between calculated and measured E-values, pointing that Equation 7 should not be used for prediction of E-value of GP concrete. The values of static Poisson's ratio of GP concrete fall in the range of typical values for OPC mortars and concretes, between 0.1 and 0.2 (Alexander, 1994). 
Heat curing of GP concrete is accompanied by volume changes due to chemical reaction, water evaporation, thermal movement, etc. and will possibly lead to internal stresses and the formation microcracks as a result. Shrinkage behavior of alkali-activated fly ash concretes during heat curing was not previously investigated. The results of early age shrinkage of both concretes during the first 24 hours are presented in Figure 2. During the first 24 hours, GP was cured in oven at $60{ }^{\circ} \mathrm{C}$, while OPC-FA concrete was cured in fog room at $25^{\circ} \mathrm{C}$.

The maximum vertical displacement of OPC-FA concrete after 24 hours was more than 2800 microstrain. During the first hours, depending on setting time, concrete is in the plastic state and settlement is present. Holt (2001) stated that at the age of about 2 hours after mixing the clear measurements of autogenous shrinkage of cement paste begins as a paste formed some skeleton. The solid curve on Figure 2, attributed to vertical displacement of OPC-FA concrete, has distinctive points of inflection. Point A appeared within one hour of mixing. The concrete was definitely still in plastic state, thus the vertical displacement in this period can be attributed to settlement movements. The rate of settlement then slows down due to the development of a loose internal skeleton (Holt, 2001) and initial setting of concrete (point B appeared after about 2.2 hours after mixing) occur. Point B is the starting point for measuring autogenous shrinkage of OPC-FA concrete. The maximum value of autogenous shrinkage of OPC-FA concrete is about 740 microstrain, which is $0.74 \mathrm{~mm} / \mathrm{m}$. Holt (2001) reported a magnitude of autogenous shrinkage of about $1.1 \mathrm{~mm} / \mathrm{m}$ for concrete with $\mathrm{w} / \mathrm{c}$ ratio of 0.35 , which is in the same order of magnitude that the results obtained in this investigation.

Early age shrinkage of GP concrete after 24 hours is about 1460 microstain, which is higher than the autogenous shrinkage of OPC-FA concrete but much lower than total shrinkage of OPC-FA after 24 hours. There are no other inflection points on the GP graph except the maximum shrinkage value at point about 1 hour (point $A_{1}$ ) after measurement started. The steep slope from zero to point $A_{1}$, similar to that of the OPC-FA graph (from zero to A point) suggests that during the first hour in the oven GP concrete was in a plastic state and then hardens very quickly compare to OPC-FA, as there is no other point of inflection on the graph. The GP graph changed it direction towards shrinkage reduction 
suggesting that there was sample expansion caused by the elevated temperature in the oven. The maximum shrinkage value of GP concrete was observed after about 1 hour in the oven, while the maximum shrinkage value of OPC-FA concrete was observed after 6 hours (point C) with insignificant increase up to 20 hours. The difference in curing condition might explain shrinkage rate differences between these two concretes. The dissolution of the amorphous fly ash phase in GP concrete, condensation and reorganization of binder structure overlaps each other (Palomo et al., 1999) and the elevated temperature only accelerates the process of alkali-activation. Lee (2007) reported shrinkage during the first 24 hours of more than 2200 microstrains for ambient cured high calcium fly ash-slag concrete activated by sodium silicate solution with greywacke chip and fine dune sand as coarse and fine aggregates. The author concluded that inorganic polymer have a very high early age shrinkage potential and rate of shrinking. However results of the present study show that OPC-FA concrete experienced much higher early age shrinkage than that of GP, even though the GP concrete was cured in an oven.

Drying shrinkage of the concretes is shown in Figure 3. It can be seen that drying shrinkage of OPCFA is about 500 microstrain, while the drying shrinkage of GP is about 360 microstrain after one year. The drying shrinkage of GP concrete was expected to be lower compared to OPC-FA as the major part of shrinkage occurred during heat curing. Sagoe-Crentsil et al. (2013) reported values of drying shrinkage for $40 \mathrm{MPa}$ geopolymer and OPC concretes (both of them steam cured at $60{ }^{\circ} \mathrm{C}$ ) of 350 and 500 microstrain respectively. Wallah and Rangan (2006) reported drying shrinkage of 100 microstrain for higher strength geopolymer concrete. It is important to not underestimate the shrinkage movements of concrete during the first 24 hours as this might result in the occurrence of cracks. Hence, more research is needed on early age shrinkage of alkali-activated fly ash pastes, mortars and concretes.

Creep behaviour of both concretes was studied for a period of one year. For the first set of GP concrete samples, creep test began immediately after heat curing. The second set of samples was placed under sustained stress after 28 days of curing. Table 5 presents sustained stress and 
instantaneous (elastic) strain measured immediately after the application of sustained load. Instantaneous elastic modulus was calculated as sustained stress/instantaneous strain. The values of instantaneous elastic modulus are similar to those presented earlier in Table 4, suggesting good repeatability of the results.

Creep performance of both GP and OPC-FA concretes are shown on Figure 4. Basic creep coefficients were calculated as creep strain divided by elastic strain. In general, it can be seen that the creep deformation of GP concrete is less than that of OPC-FA concrete. After one year under load, the creep coefficient for OPC-FA concrete was higher than 1.2, while it was only 0.4 for GP concrete.

Sagoe-Crentsil et al. (2013) reported a basic creep coefficient of 0.6 for 40 MPa geopolymer concrete, while for OPC the concrete creep coefficient was about 1.8 (both concretes were steam cured). The authors explained the smaller creep strains for geopolymer concrete due to partially unreacted fly ash particles, which act as a "micro-aggregates" and provide the restrain effect. Wallah and Rangan (2006) obtained creep coefficient between 0.6 and 0.7 for heat cured geopolymer. The results presented in this section have trends similar to the results published by other researchers. However, due to difference in aggregate type and ratio, age of concrete and other factors the results cannot be compared.

\subsection{Durability}

Oxygen permeability, water sorptivity and chloride conductivity test methods have been developed in by Alexander, Ballim and Mackenchnie (1999) to characterise the transport properties of concrete. Test results are presented in Table 6 for both, GP and OPC-FA concretes.

Although the durability index approach is not widely used outside of South Africa, a comparison with internationally accepted methods for concrete durability characterization was performed by Beushausen and Alexander (2008). The results shows that oxygen permeability and chloride conductivity test methods can be successfully used in characterising concrete durability and have 
similar merit in establishing material properties as other internationally accepted methods. In general, the higher the OPI index, the more resistant the concrete to gas penetration (Alexander et al, 2008). The OPI indexes of GP concrete are similar to those of OPC-FA concrete. The limits of durability index values for classification of concrete in terms of durability are presented elsewhere (Alexander and Magee, 1999; Olorunsogo and Padayachee, 2002). According to these values the oxygen permeability index of both GP and OPC-FA concretes is excellent.

Significantly better water sorptivity was found for OPC-FA concrete compare to GP concretes. Water sorptivity of GP concretes falls in the 'poor' category, while the sorptivity of OPC-FA is good. These results correlate well with the porosity test, showing that the porosity of GP concretes is higher compared to that of OPC-FA concrete. It seems that post-curing conditions do not affect the unidirectional absorption of samples.

The chloride conductivity test monitors the diffusion of chloride ions through the concrete sample saturated with a $\mathrm{NaCl}$ solution by means of using a voltage potential difference and measuring the electrical current. In general the lower the chloride conductivity value, the more resistant the concrete is. Both GP and OPC-FA concretes have similar values of chloride conductivity with slightly lower value for OPC-FA concrete. It means that both concretes have similar resistance to chloride ion penetration. The performance of both concretes is good, according to recommended values for durability classification (Olorunsogo and Padayachee, 2002). There is again a correlation between porosity and chloride conductivity value. Higher porosity makes it easier for chloride ions to penetrate the concrete matrix.

\section{Conclusions}

The following conclusions can be made on the base of laboratory test performed on alkali-activated fly ash concrete: 
- $\quad$ Alkali-activated fly ash concrete developed good mechanical strength at 28 days (45.5 MPa in compression, 5.8 MPa flexural and 3.7 MPa splitting cylinder) after initial heat curing at $60{ }^{\circ} \mathrm{C}$ for 24 hours;

- Values for compressive strength, modulus elasticity, Poisson's ratio, creep and shrinkage were similar to that of blended Portland cement - fly ash concrete;

- $\quad$ The total early age shrinkage of alkali-activated fly ash concrete during heat curing was lower than that of blended ordinary Portland cement - fly ash concrete cured in fog room, 1460 microstrain compared to 2800 microstain;

- $\quad$ Alkali-activated fly ash concrete displayed good drying shrinkage (360 microstrain) and creep (200 microstrain) performance in comparison to the blended Portland cement - fly ash concrete (500 and 600 microstrains respectively);

- $\quad$ Oxygen permeability and chloride conductivity of alkali-activated fly ash concrete is comparable to those values for blended Portland cement - fly ash concrete, while water sorptivity is higher, as a result of the relatively high porosity of alkali-activated fly ash concrete;

- $\quad$ Alkali-activated fly ash concrete with a good performance can be produced.

More research is needed on early age shrinkage of alkali-activated fly ash pastes, mortars and concretes during ambient and heat curing. It is necessary to study factors affecting early age shrinkage and its magnitude with the aim to quantify the induced stress. The understanding of early age shrinkage development of alkali-activated fly ash materials is important as it may be responsible for early age cracking.

\section{References}

Addis BJ (1994) Strenght of hardened concrete. In Fulton's concrete technology (Addis BJ (ed.)) 7th edn. Portald Cement Institute, Midrand, South Africa, pp. 97-106. 
Alexander MG (1994) Deformation and volume change of hardened concrete. In Fulton's concrete technology (Addis BJ (ed.)) 7th edn. Portald Cement Institute, Midrand, South Africa, pp. 107152.

Alexander MG, Ballim Y, Mackechnie JR (1999) Concrete durability index testing manual. Department of Civil Engineering, University of Cape Town, University of the Witwatersrand, South Africa, Research monograph No 4.

Alexander MG, Ballim, Y, Stanish K (2008) A framework for use of durability indexes in performance-based design and specifications for reinforced concrete structures. Materials and structures 41: 921-936.

Alexander MG, Davis DE (1992) The influence of aggregate on the compresiive strength and elastic modulus of concrete. Die siviele ingenieur in Suid-Afrika May, pp. 161-170.

Alexander MG, Magee BJ (1999) Durability performance of concrete containing condenced silica fume. Cement and Concrete Research 29: 917-922.

Ambily PS, Ravisankar K, Umarani C, Dattatreya JK, Iyer NR (2014) Development of ultra-highperformance geopolymer concrete. Magazine of Concrete Research 66(2): 82-89.

Beushausen H, Alexander MG (2008) The South African durability index tests in an international comparison. Journal of the South African Institution of Civil Engineering 50(1): 25-31.

Bakharev T (2005) Geopolymeric material prepared using Class F fly ash and elevated temperature curing. Cement and Concrete Research 35: 1224-1232.

Criado M, Fernández-Jiménez A, Palomo A (2010) Alkali activation of fly ash. Part III: Effect of curing conditions on reaction and its graphical description. Fuel 89: 3185-3192.

Eppers S, Müller C (2010) The shrinkage cone method for measuring the autogenous shrinkage - an alternative to the corrugated tube method. In International RILEM Conference on Use of Superabsorbent Polymers and Other New Additives in Concrete Lyngby, Denmark (Jensen OM, Hasholt MT and Laustsen S (eds)). RILEM Publications SARL, pp. 67-76.

Fernández-Jiménez A, Palomo A, López-Hombrados C (2006) Engineering properties of alkaliactivated fly ash concrete. ACI Materials Journal 3(2): 106-112. 
Ferreira LF, Costa HSS, Barata IIA et al. (2014) Precast alkali-activated concrete towards sustainable construction. Magazine of Concrete Research 66(12): 618-626.

Hardjito D, Rangan BV (2005) Development and properties of low-calcium fly ash-based geopolymer concrete. Faculty of Engineering, Curtin University of Technology, Perth, Australia. Research Report GC 1, pp. 1-94.

Heath A, Paine K, McManus M (2014) Minimising the global warming potential of clay based geopolymers. Journal of Cleaner Production 78: 75-83.

Holt EE (2001) Early age autogenous shrinkage of concrete. VTT Building and Transport, Technical Research Centre of Finland. VT Publications 446, pp. 1-184.

Kovalchuk G, Fernández-Jiménez A, Palomo A (2007) Alkali-activated fly ash: Effect of thermal curing conditions on mechanical and microstructural development - Part II. Fuel 86: 315-322.

Lee NP (2007) Creep and shrinkage of inorganic polymer. Branz, New Zealand. Study report No 175, pp. 1-27. See http://www.branz.co.nz/cms_show_download.php?id=94f6c2bd2a896849d7fa2d3664b87551bd54 e62c (accessed 19/08/2014).

McLellan BC, Williams RP, Lay J, van Riessen A, Corder GD (2011) Costs and carbon emissions for geopolymer pastes in comparison to ordinary Portland cement. Journal of Cleaner Production 19: 1080-1090.

Olorunsogo FT, Padayachee N (2002) Performance of recycled aggregate concrete monitored by durability indexes. Cement and Concrete Research 32: 179-185.

Palomo A, Grutzeck MW, Blanko MT (1999) Alkali-activated fly ashes A cement for the future. Cement and Concrete Research 29: 1323-1329.

Rangan BV (2009) Engineering properties of geopolymer concrete. In Geopolymer: Structure, processing, properties and industrial applications. Part II. Manufacture and properties of geopolymer (Provis JL, van Deventer JSJ, (eds.)). Woodhead Publishing Limited, Cambridge, UK, pp. 211-226.

Reddy DV, Edouard JB, Sobhan K (2013) Durability of fly ash-based geopolymer structural concrete in the marine environment. Journal of Materials in Civil Engineering 25(6): 781-787. 
Sagoe-Crentsil K, Brown T, Taylor A (2013) Drying shrinkage and creep performance of geopolymer concrete. Journal of Sustainable Cement-Based Materials 2(1): 35-42.

Sofi M, van Deventer JSJ, Mendis PA, Lukey GC (2007) Engineering properties of inorganic polymer concretes (IPCs). Cement and Concrete Research 34: 251-257.

Turner LK, Collins FG (2013) Carbon dioxide equivalent $\left(\mathrm{CO}_{2}-\mathrm{e}\right)$ emissions: A comparison between geopolymer and OPC cement concrete. Construction and Building Materials 43: 125-130.

Wallah SE, Rangan BV (2006) Low-calcium fly ash-based geopolymer concrete: long-term properties. Perth, Australia: Faculty of Engineering, Curtin University of Technogy. Research Report GC 2, pp. 1-97. 
Figure captions

Figure 1. Strength development of GP and OPC-FA blended concretes

Figure 2. In-situ shrinkage of OPC-FA and GP concretes during the first 24 hours

Figure 3. Drying shrinkage of OPC-FA and GP concretes

Figure 4. Creep performance of GP and OPC-FA concretes 
Table captions

Table1. Chemical composition of fly ash and OPC, $\%$

Table 2. Concrete mix proportions, $\mathrm{kg} / \mathrm{m}^{3}$

Table 3. Modulus of rupture and split tensile strength (standard deviation) of GP and OPC-FA concrete at 28 days

Table 4. E-values (standard deviation) and Poisson's ratios of GP and OPC-FA concrete at 28 days

Table 5. Instantaneous strain and elastic modulus of GP and OPC-FA concretes

Table 6. Durability results 
Table1. Chemical composition of fly ash and OPC, $\%$

\begin{tabular}{ccc}
\hline & $\begin{array}{c}\text { Lethabo fly } \\
\text { ash }\end{array}$ & $\begin{array}{c}\text { CEM I } \\
\mathbf{5 2 . 5 N}\end{array}$ \\
\hline $\mathrm{SiO}_{2}$ & 55.83 & 20.53 \\
$\mathrm{TiO}_{2}$ & 1.56 & 0.31 \\
$\mathrm{Al}_{2} \mathrm{O}_{3}$ & 30.25 & 4.83 \\
$\mathrm{Fe}_{2} \mathrm{O}_{3}$ & 3.92 & 2.21 \\
$\mathrm{MnO}$ & 0.03 & 0.86 \\
$\mathrm{MgO}$ & 1.13 & 3.62 \\
$\mathrm{CaO}$ & 4.05 & 62.89 \\
$\mathrm{Na} 2 \mathrm{O}$ & 0.16 & $<0.01$ \\
$\mathrm{~K}_{2} \mathrm{O}$ & 0.75 & 0.40 \\
$\mathrm{P}_{2} \mathrm{O}_{5}$ & 0.43 & 0.05 \\
$\mathrm{Cr}_{2} \mathrm{O}_{3}$ & 0.04 & 0.05 \\
$\mathrm{NiO}$ & 0.02 & 0.04 \\
$\mathrm{~V}_{2} \mathrm{O}_{5}$ & 0.03 & $<0.01$ \\
$\mathrm{ZrO}_{2}$ & 0.05 & $<0.01$ \\
$\mathrm{SO}_{3}$ & - & 1.81 \\
$\mathrm{SrO}_{2}$ & - & 0.02 \\
$\mathrm{LOI}$ & 0.86 & 2.38 \\
\hline
\end{tabular}


Table 2. Concrete mix proportions, $\mathrm{kg} / \mathrm{m}^{3}$

\begin{tabular}{ccc}
\hline Material & GP & OPC-FA \\
\hline Fly ash & 500 & 150 \\
CEM I 52.5 N & - & 350 \\
9.5-mm dolomite stone & 1113 & 1158 \\
Dolomite sand & 603 & 623 \\
NaOH & 58 & - \\
Water & 150 & 200 \\
Theoretical density & 2424 & 2481 \\
\hline
\end{tabular}


Table 3. Modulus of rupture and split tensile strength (standard deviation) of GP and OPC-FA concrete at 28 days

\begin{tabular}{ccccc}
\hline & \multicolumn{2}{c}{$\begin{array}{c}\text { Measured tensile strength and } \\
\text { standard deviation (in brackets), } \\
\text { MPa }\end{array}$} & \multicolumn{2}{c}{$\begin{array}{c}\text { Calculated tensile strength , } \\
\text { MPa }\end{array}$} \\
\cline { 2 - 5 } & Flexural & Split & $\begin{array}{c}\text { Flexural } \\
\text { (Equation 5) }\end{array}$ & $\begin{array}{c}\text { Split } \\
\text { (Equation 6) }\end{array}$ \\
\hline GP dry & $5.8(0.12)$ & $3.7(0.26)$ & 4.6 & 3.1 \\
GP water & $4.5(0.32)$ & $3.8(0.31)$ & 4.6 & 3.0 \\
GP dry +24 h in water & $5.5(0.46)$ & $2.5(0.03)$ & 4.6 & 3.1 \\
OPC-FA & $7.1(0.33)$ & $4.1(0.28)$ & 5.3 & 3.7 \\
\hline
\end{tabular}


Table 4. E-values (standard deviation) and Poisson's ratios of GP and OPC-FA concrete at 28 days

\begin{tabular}{ccc}
\hline & \multicolumn{2}{c}{ Deformation } \\
\cline { 2 - 3 } & E-value (GPa) & Poisson's ratio \\
\hline GP dry & $32.9(1.38)$ & 0.11 \\
GP water & $30.7(1.00)$ & 0.12 \\
GP dry + 24 h in water & $32.2(1.18)$ & 0.12 \\
OPC-FA & $43.5(0.03)$ & 0.12 \\
\hline
\end{tabular}


Table 5. Instantaneous strain and elastic modulus of GP and OPC-FA concretes

\begin{tabular}{ccccc}
\hline & $\begin{array}{c}\text { Cube } \\
\text { compressive } \\
\text { strength, } \\
\text { MPa }\end{array}$ & $\begin{array}{c}\text { Sustained } \\
\text { stress, MPa }\end{array}$ & $\begin{array}{c}\text { Instantaneous } \\
\text { (elastic) strain, } \\
\text { microstrain }\end{array}$ & $\begin{array}{c}\text { Instantaneous } \\
\text { elastic } \\
\text { modulus, GPa }\end{array}$ \\
\hline GP after heat curing & 32.5 & 10.87 & 364 & 29.8 \\
GP after 28 days & 45.5 & 14.54 & 486 & 29.9 \\
OPC-FA after 28 days & 61.3 & 19.64 & 468 & 41.9 \\
\hline
\end{tabular}


Table 6. Durability results

\begin{tabular}{ccccc}
\hline & OPI & $\begin{array}{c}\text { Water } \\
\text { sorptivity, } \\
\mathbf{m m} / \mathbf{h}^{\mathbf{1 / 2}}\end{array}$ & $\begin{array}{c}\text { Chloride } \\
\text { conductivity, } \\
\mathbf{m S} / \mathbf{c m}\end{array}$ & Porosity, \% \\
\hline GP dry & 10.06 & 12.6 & 1.44 & 13.0 \\
GP water & 10.21 & 12.6 & 1.32 & 11.1 \\
OPC-FA & 10.56 & 8.1 & 1.14 & 9.1 \\
\hline
\end{tabular}




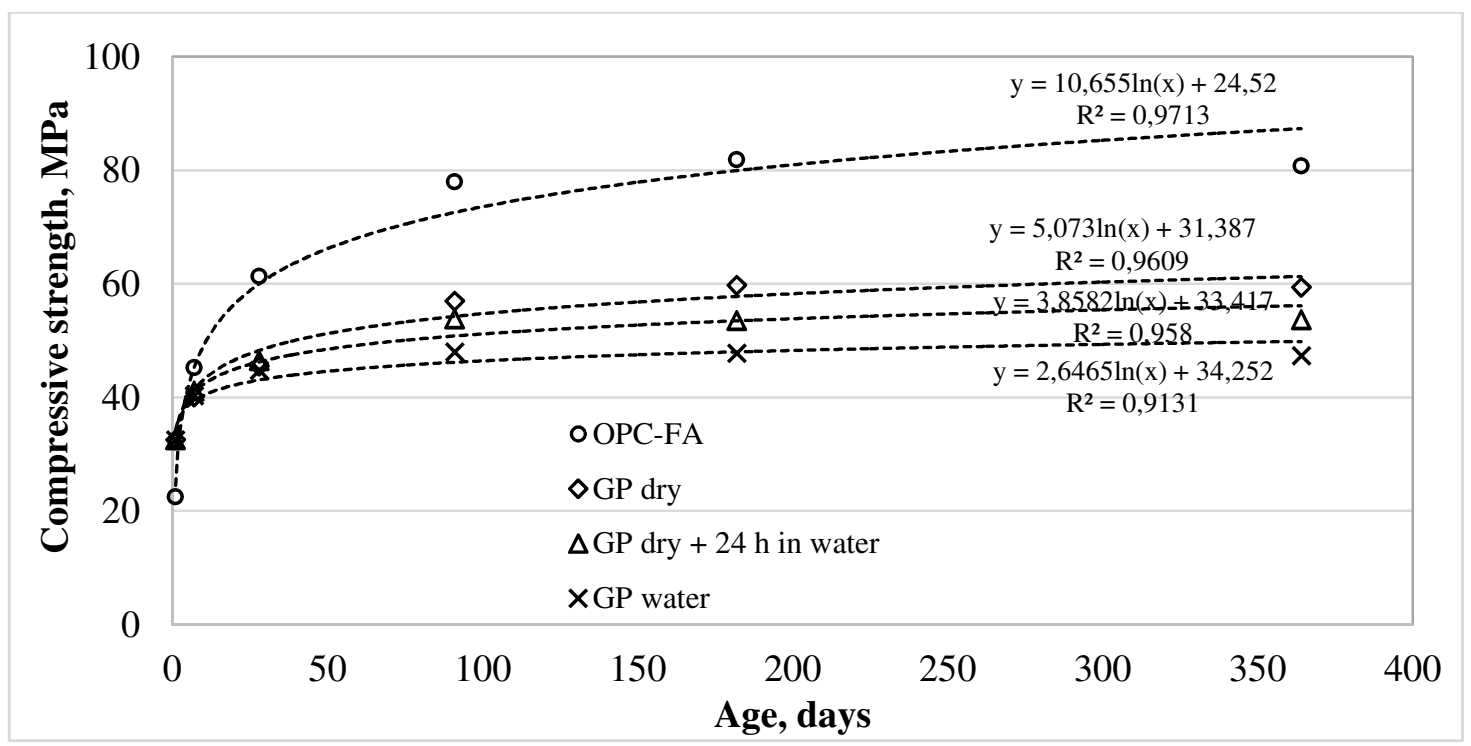

Figure 1 


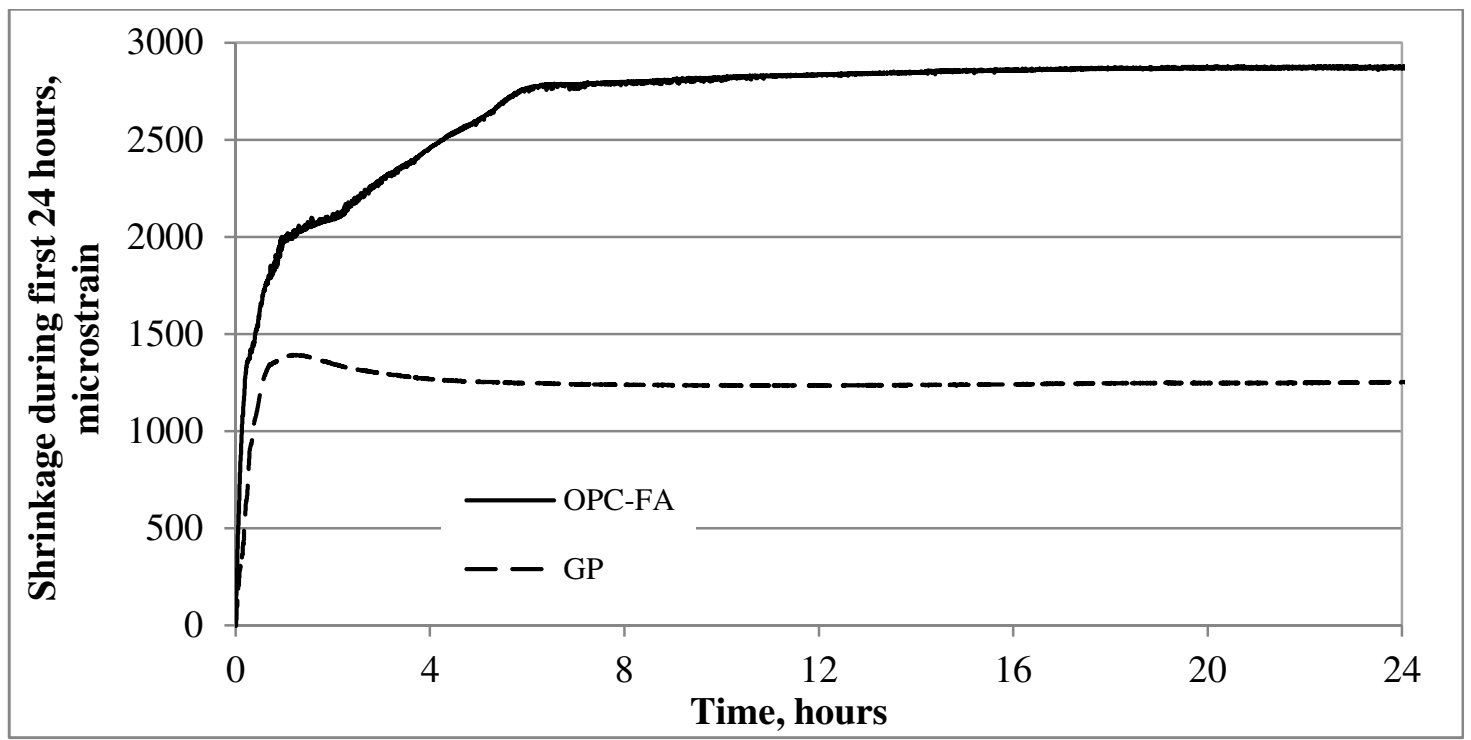

Figure 2 


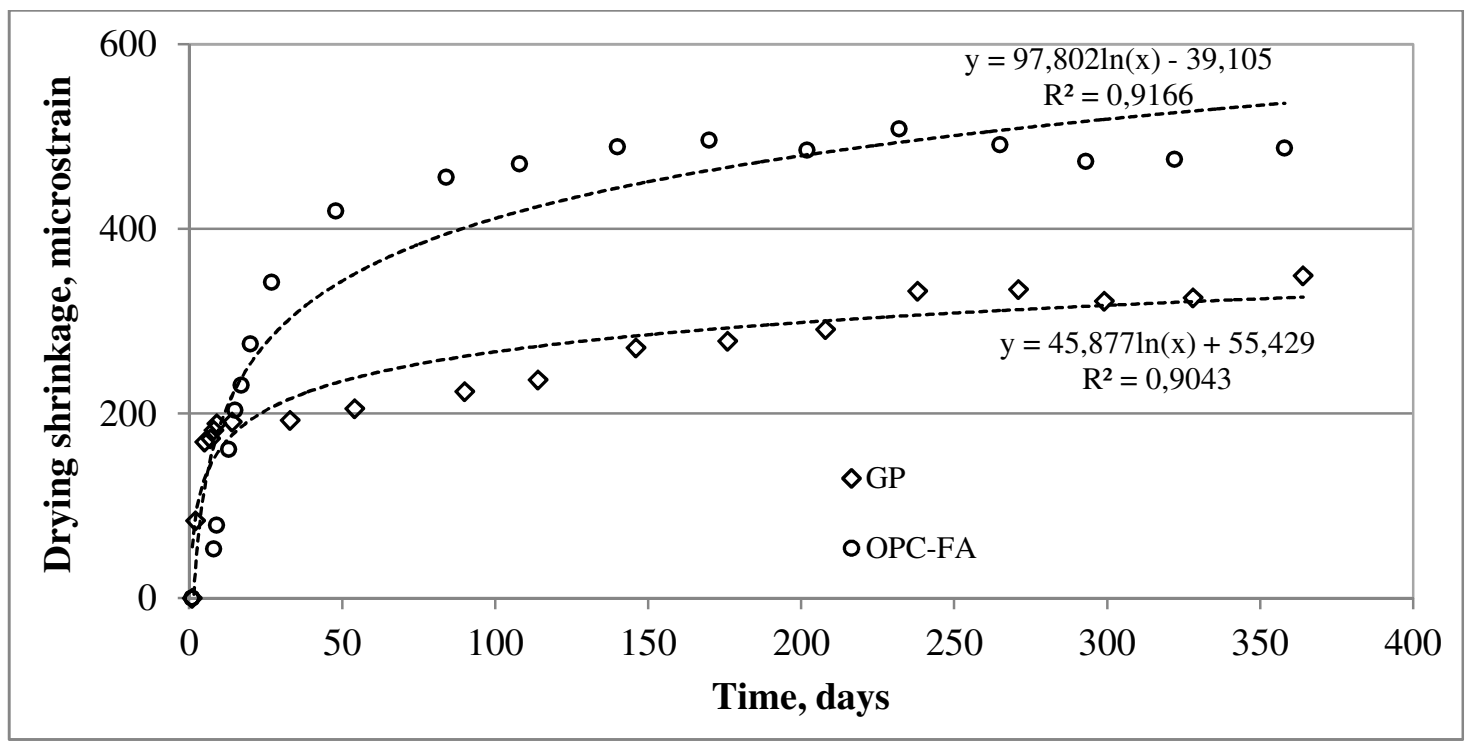

Figure 3 


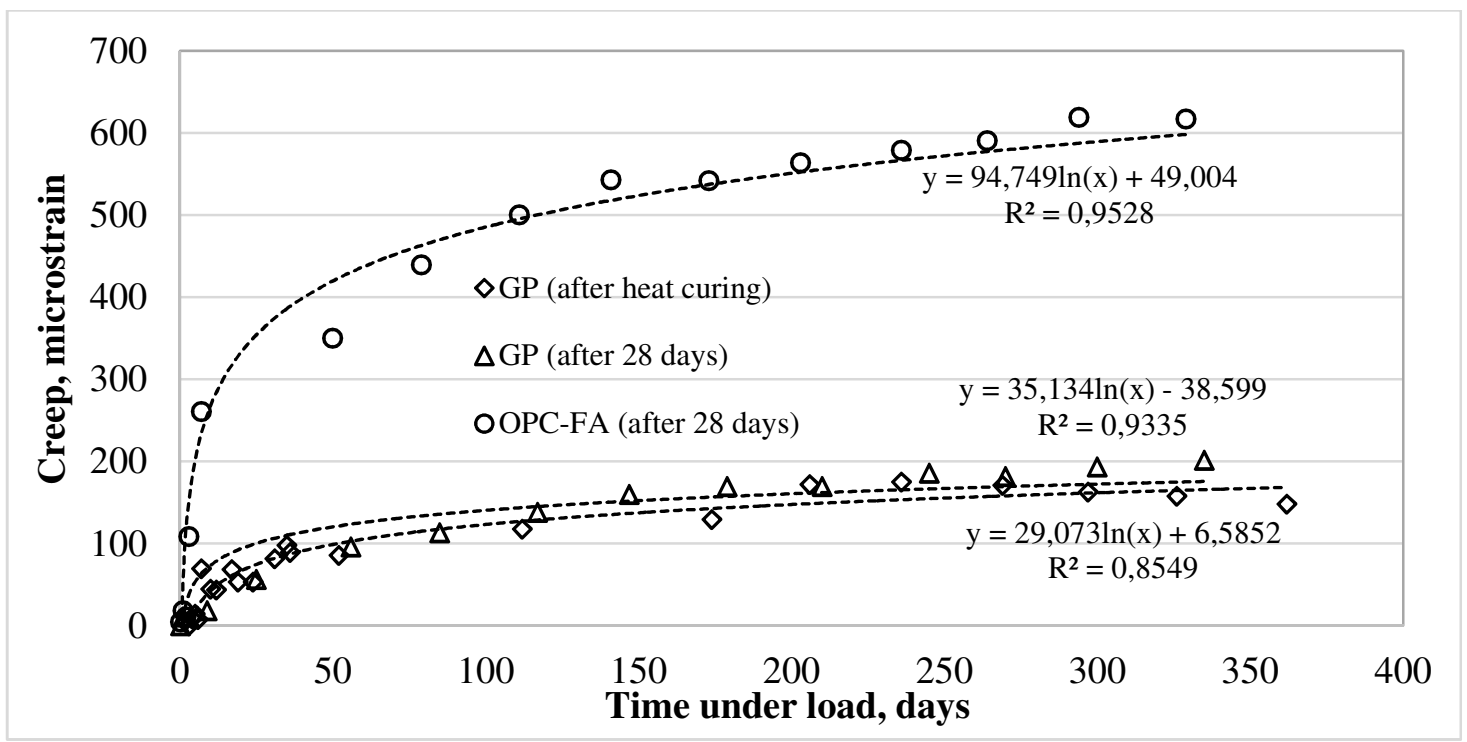

Figure 4 